\title{
Activity period of Southern house wren Troglodytes musculus Naumann, 1823 (Passeriformes: Troglodytidae) on edges of Atlantic Forest fragments in João Pessoa (State of Paraíba, Northeast Brazil)
}

\section{Daniel Silva Lula Leite ${ }^{1}$, Natan Diego Alves de Freitas ${ }^{2}$, Wilson Marques de Oliveira Junior ${ }^{3}$ and Anna Carolina Nogueira Borzani ${ }^{4}$}

${ }^{1}$ Programa de Pós-Graduação em Desenvolvimento e Meio Ambiente (Prodema). Centro de Ciências Exatas e da Natureza. Universidade Federal da Paraíba. João Pessoa-PB, Brazil (CEP 58051-085). Email: dan_jpb@hotmail.com.

${ }^{2}$ Programa de Pós-Graduação em Ciências Biológicas (Zoologia). Centro de Ciências Exatas e da Natureza. Universidade Federal da Paraíba. João Pessoa-PB, Brazil (CEP 58051-085).

${ }^{3}$ Centro de Ciências Exatas e da Natureza. Curso de Graduação em Ciências Biológicas. Universidade Federal da Paraíba. João Pessoa-PB, Brazil (CEP 58051085).

${ }^{4}$ Programa de Pós-Graduação em Psicobiologia. Centro de Biociências. Universidade Federal do Rio Grande do Norte. Av. Salgado Filho, S/No. Natal-RN, Brazil (CEP 59078-970).

Abstract. Southern house wren Troglodytes musculus Naumann, 1823 (Passeriformes: Troglodytidae) is widely distributed in Brazil, occurring on the edges of forests and urban areas, considerable a passeriform usually found in antropized landscape. Birds use vocal signs in diverse activities during the circadian cycle (eg.: in reproduction, territorial defense, alert of predators and competitors, individual recognition, etc), employing vocal signs under energetic balance for development of diary activities. The aim of this study was to evaluate the diary activity period of $T$. musculus through their vocalizations. The sampling were made during two days in edges of Atlantic Forest fragments in João Pessoa, State of Paraíba, Brazil. Using the method of playback, vocal response of Southern house wren was measured in six periods for each day: $\mathrm{H} 1$ ( $5 \mathrm{~h}-7 \mathrm{~h}), \mathrm{H} 2(7 \mathrm{~h}-9 \mathrm{~h})$, H3 $(9 \mathrm{~h}-11 \mathrm{~h}), \mathrm{H} 4 \quad(11 \mathrm{~h}-13 \mathrm{~h}), \mathrm{H} 5 \quad(13 \mathrm{~h}-15 \mathrm{~h})$ and H6 (15 h-17 h). Differences among the periods was tested through of Kruskall-Wallis test, and Mann-Whitney test with Bonferroni's corrections. In order to separate the periods groups, was applied Cluster test and non-Metric Multidimensional Scaling. Were registered 2,421 vocalizations, which 2,229 in morning (H1 to $\mathrm{H} 3$ ) and 122 (H4 to $\mathrm{H} 6)$ in the afternoon period. Results indicated there were differences among the diary activities period of T. musculus ( $\mathrm{p}=0.0008171$ ), with early hours of morning ( $\mathrm{H} 1$ and $\mathrm{H} 2$ ) did not differ between each other
Received

February 02, 2018

Accepted

April 13, 2018

Released

April 30, 2018

Full Text Article

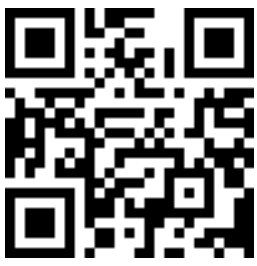

ORCID

D) 0000-0001-9104-7418 Daniel Silva Lula Leite (ㄷ) 0000-0002-0858-3269 Natan Diego Alves de Freitas 
( $p=0.183$ ), however differing from the others. The H3 and H6 periods also not differ between each other $(p=0.784)$, but differing significantly from $\mathrm{H} 4$ and $\mathrm{H} 5$, that did not record no one vocalization $(p=1)$. Cluster analyses support these results, clustering: Group 1 (H1 and H2); Group 2 (H4 and H5) and Group 3 (H3 and H6). The periods with the highest frequencies of vocal sings (Group 1) showed the most favorable conditions to vocalize, be they microclimatic (better sound transmission due lowest wind intensity and air turbulence) or behaviors (females attraction, territorial invasion, etc.). On the other hand, non-recording of vocalizations of Group 2 suggest unfavorable periods to vocalize. In addition, Southern house wren concentrate their energetic reserves foraging in these periods. The intermediary records of Group 3 indicate that the periods $\mathrm{H} 3$ and $\mathrm{H} 6$ require an expensive energetic cost to vocalize due the lowest success in an effective communication. In that way, this present study suggest there was a pattern in diary activity period in Southern House Wren populations evaluated, with no overlap of activities, complementing the knowledge of the specie biology and behavior.

Keyword: Southern house wren; Period of activity; Vocalization; Edges of Atlantic Forest fragments.

\section{Introduction}

Southern house wren Troglodytes musculus Naumann, 1823 (Passeriformes: Troglodytidae) has about $12 \mathrm{~cm}$ of total length, is brown colored and it belongs to the Family Troglodytidae, which includes mostly endemic birds in American continent. Their geographic distribution extends from Canada to Southern Chile and Argentina, having the largest distribution in the southern hemisphere (Sick, 2001).

Although it is classified as insectivorous (Marini, 2001; Blendinger, 2005), Southern house wrens also eats seeds and fruit (Voss and Sander 1980; Sick 1997). T. musculus uses a wild range of habitats, occurring in forest edges and on Cerrado biome, even urban environment as gardens and houses, nesting in almost any place with a hole, like woods, cracks, roofs or abandoned nests (Sick, 2001). Such as other family members, this species has high vocalization quality, which is hard to
(1) $0000-0002-1826-3453$

Wilson Marques de Oliveira Junior

(1) 0000-0001-9220-5983

Anna Carolina

Nogueira Borzani paraphrase (Sick, 2001), and is capable of forming duets during mating. However, this species can present cases of polygamy during mating season as highlighted by Llambías (2012).

Acoustic signals are very important for some animals in several aspects (Maynard-Smith and Harper, 2003). Birds vocals signals assist in reproduction (males attracting females and stimulating them), territory defense (males repelling rivals), individual recognition and warning for predators and competitors (Kroodsma and Byers, 1991; Fasanella and Fernández, 2009). Despite the advantages and disadvantages in using of vocal songs, it still was an evolutionary success to the majority of bird families (Slabbekoorn and Smith, 2002).

Birds perform various activities during their circadian cycle. They have different behaviors along the day like singing, foraging and resting, for example. The energetic balance seems to be a key factor that influences the 
frequency and time in which Southern House Wren sings (Thomas, 2002). Thus, the purpose of this study was to evaluate the periods of daily activity of T. musculus by its vocalizations.

\section{Metodology}

\section{Study areas}

Sampling was carried out on Atlantic Forest fragments edges in two locations (Figure 1), Mata do Buraquinho $\left(07^{\circ} 06^{\prime} \mathrm{S}, 34^{\circ} 52^{\prime} \mathrm{W}\right)$ and Mata do Cuiá $\left(7^{\circ} 11^{\prime} \mathrm{S}, 34^{\circ} 51^{\prime} \mathrm{W}\right)$, in Municipality of João Pessoa, State of Paraíba, Northeast Brazil, during Sept. 6 and 7, 2016.

Due the construction of the BR-230 highway the Mata do Buraquinho forest was divided in two fragments, a continuous forest of 471 ha protected in "Refúgio de Vida Silvestre Mata do Buraquinho", and 11 small fragments inside of the limits of the Federal University of Paraíba campus (Dias, 2006).

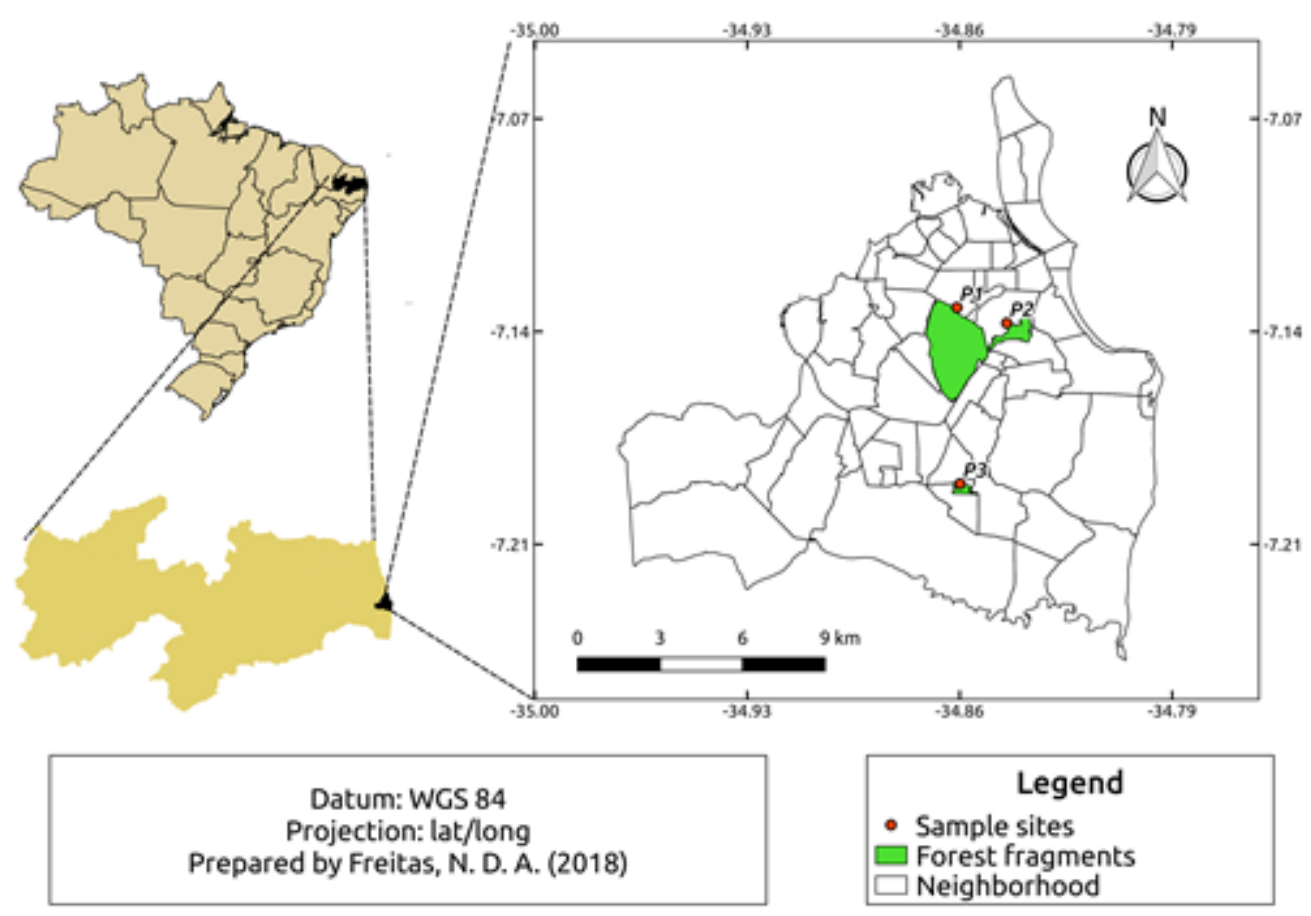

Figure 1. Detail of the study areas and sampling points.

Mata do Cuiá (20.8 ha) is located at the Parque Natural Municipal do Cuiá that has areas of intensive and restricted use (Lima, 2012). The relief of the area presents coastal sedimentary plains or tablelands (dominant form), characterized by surfaces that interpose, dividing the river basin development of Cuiá. Mata do Cuiá represents a remnant of vegetation of the Atlantic Forest biome at an advanced stage of regeneration, representing $49.44 \%$ of the total area of the Parque Natural Municipal do Cuiá, being considered as the sector of greater relevance for conservation, therefore, of restricted use (Silva and Braga, 2017).

According to the climatic classification proposed by Köppen (1901) and Alvares et al. (2014), the climate of the region is As', characterized by being hot and humid, which exerts strong conditioning on the local 
environment. The rainy season begins in March and runs through August. The dry season begins in September and lasts until February. Temperature indices vary between $26^{\circ} \mathrm{C}-27^{\circ} \mathrm{C}$ and annual average rainfall does not normally exceed 2,000 mm (Silva and Braga, 2017).

\section{Sampling design}

Were established three collection points at the edge of the forest board fragments:

P1 - located next to Refúgio de Vida Silvestre Mata do Buraquinho (707' 55.4" S, 34 51' 39.1" W)

P2 - located in the domains of the campus I of Universidade Federal da Paraíba ( $7^{\circ} 08^{\prime} 14.2^{\prime \prime} \mathrm{S}, 34^{\circ} 50^{\prime} 40^{\prime \prime} \mathrm{W}$ ), and

P3 - located in Geisel Neighborhood near to Mata do Cuiá $\left(7^{\circ} 11^{\prime} 24.4^{\prime \prime} \mathrm{S}\right.$, $\left.34^{\circ} 51^{\prime} 35.4^{\prime \prime} \mathrm{W}\right)$.

These samples were collected during $12 \mathrm{~h}$ for two days $(\mathrm{n}=24 \mathrm{~h})$ in six different periods: $\mathrm{H} 1$ ( $5 \mathrm{~h}-7 \mathrm{~h}), \mathrm{H} 2$ (7 h-9 h), H3 (9 h-11 h), H4 (11 h-13 h), H5 (13 h-15 h) and H6 (15 h-17 h).

Was used the playback method to incite the birds vocal response or approach and facilitate visual observation. This method consists in reproducing the song and/or calling of one specific specie using a sound source (e.g. loudspeaker) (Grazinolli and MottaJunior, 2010). The goal was to quantify the vocal response of $T$. musculus during the different periods.

\section{Statistical analysis}

To analyze the period of T. musculus individual's activity was used the Kruskall-Wallis Non-Parametric Test and the Manna-Whitney Test, with Corrections of Bonferroni. The purpose was to identify differences between the sample periods. The data was submitted to the Shapiro-Wilk Normality Test and Levene Homoscedasticity Test.

In order to identify groups in relation of sample periods, Cluster's multivariate analyses and non-metric multidimensional scheduling were performed, both using Bray-Curtis Similarity Index. All analyses were performed in Past software.

\section{Results}

A total of 2,421 vocalizations (Figure 2) were recorded, being 2,299 in the morning (H1 to H3) and 122 (H4 to H6) in the afternoon (Figure 3 ).

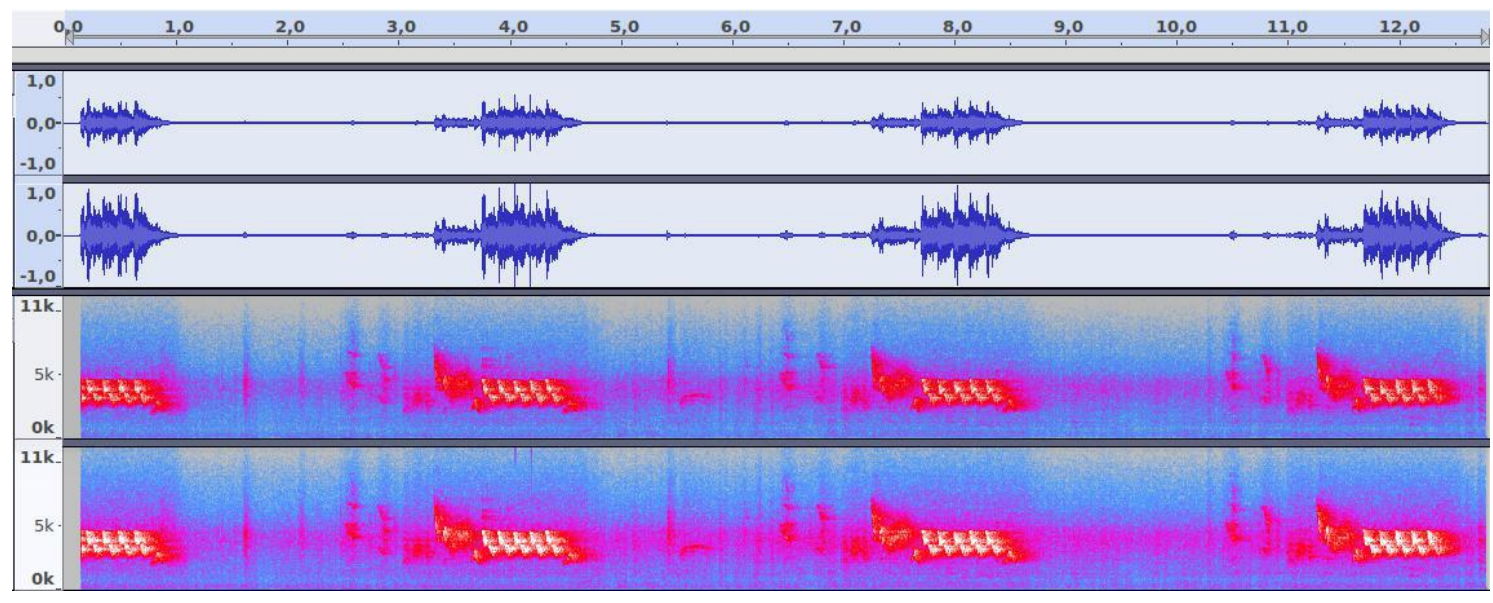

Figure 2. Southern house wren vocalization sonogram collected at sampling point P1 (next to Mata do Buraquinho Wildlife Refuge). Time (seconds) x Frequency (KHz). The colors represent the height of the vocalization, with light tones (blue) representing the sharp sound and dark tones (red) representing the bass sound. 


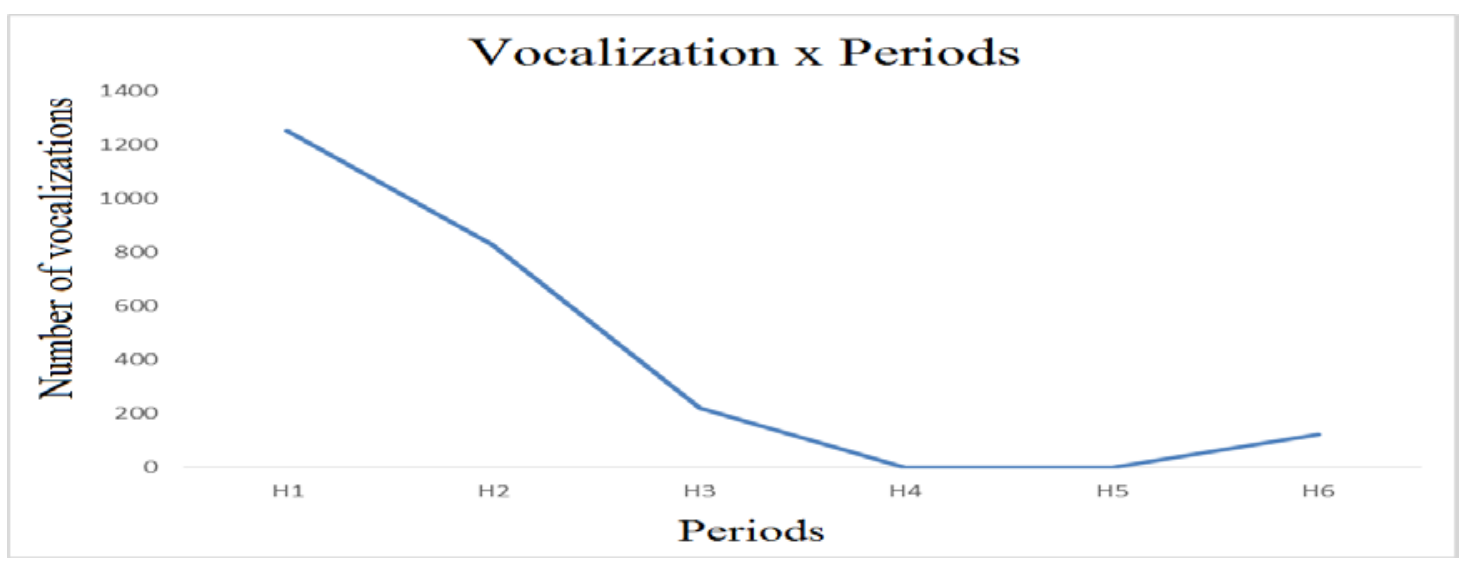

Figure 3. Number of vocalizations x sample period of Southern house wren individuals.

In face of non-normality and heteroskedasticity of the data, the Kruskal-Wallis Test indicated that there are differences in periods of activity of T. musculus $\quad(p=0.0008171)$. The posteriori test showed that individuals of Southern House Wren presented a pattern in the species activity period, with the first hours of the morning (H1 and H2) not differing between them $(p=0.183$ ), but were distinct from the others. The $\mathrm{H} 3$ and $\mathrm{H} 6$ periods also showed differences $(\mathrm{p}=0.784)$, but were significantly different from $\mathrm{H} 4$ and $\mathrm{H} 5$, which did not present any vocalization record $(p=1)$.

Cluster analysis indicates the clustering of $\mathrm{H} 1$ and $\mathrm{H} 2 \quad(80 \%$ of similarity) and the isolation of $\mathrm{H} 4$ and $\mathrm{H} 5$ (Figure 4).

\section{Periods}

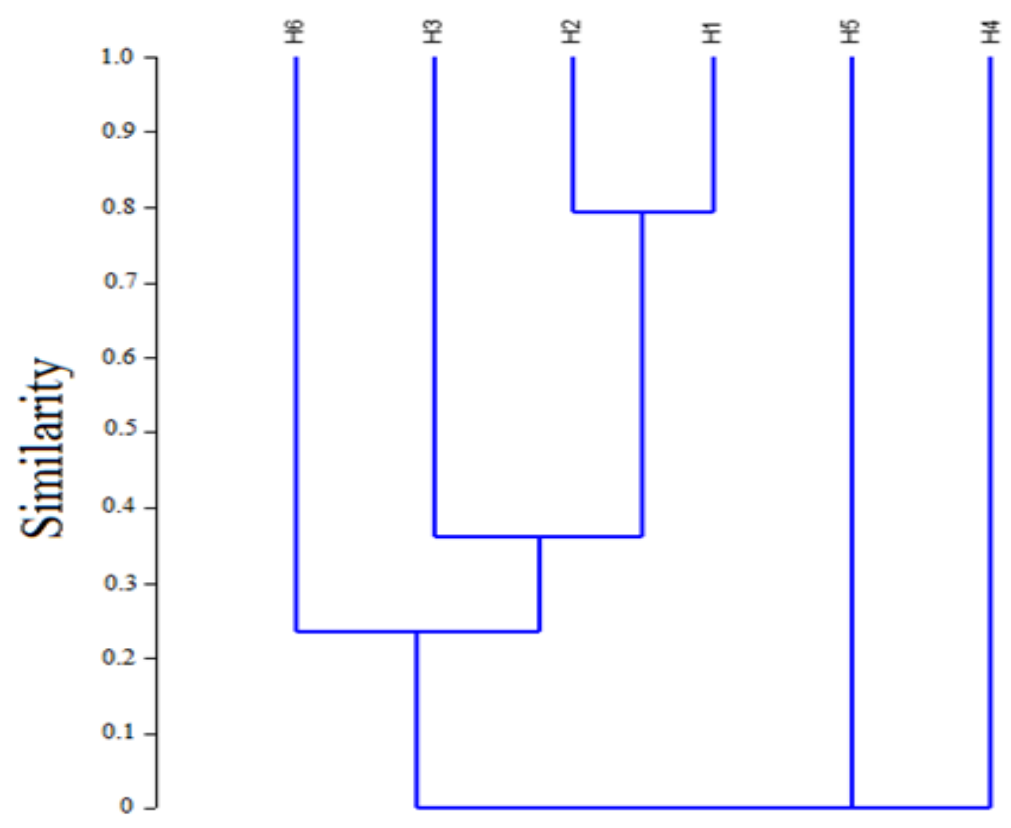

Figure 4. Cluster analysis of the sample periods of Southern house wren individuals. 
The non-metric multidimensional scheduling (nMDS) analysis also indicate the formation of 3 groups: Group 1: H1 and $\mathrm{H} 2$, with the highest vocalization values; Group 2: $\mathrm{H} 4$ and H5, with the lowest values; Group 3: H3 and H6, that presented the intermediated values between the other groups (Figure 5).

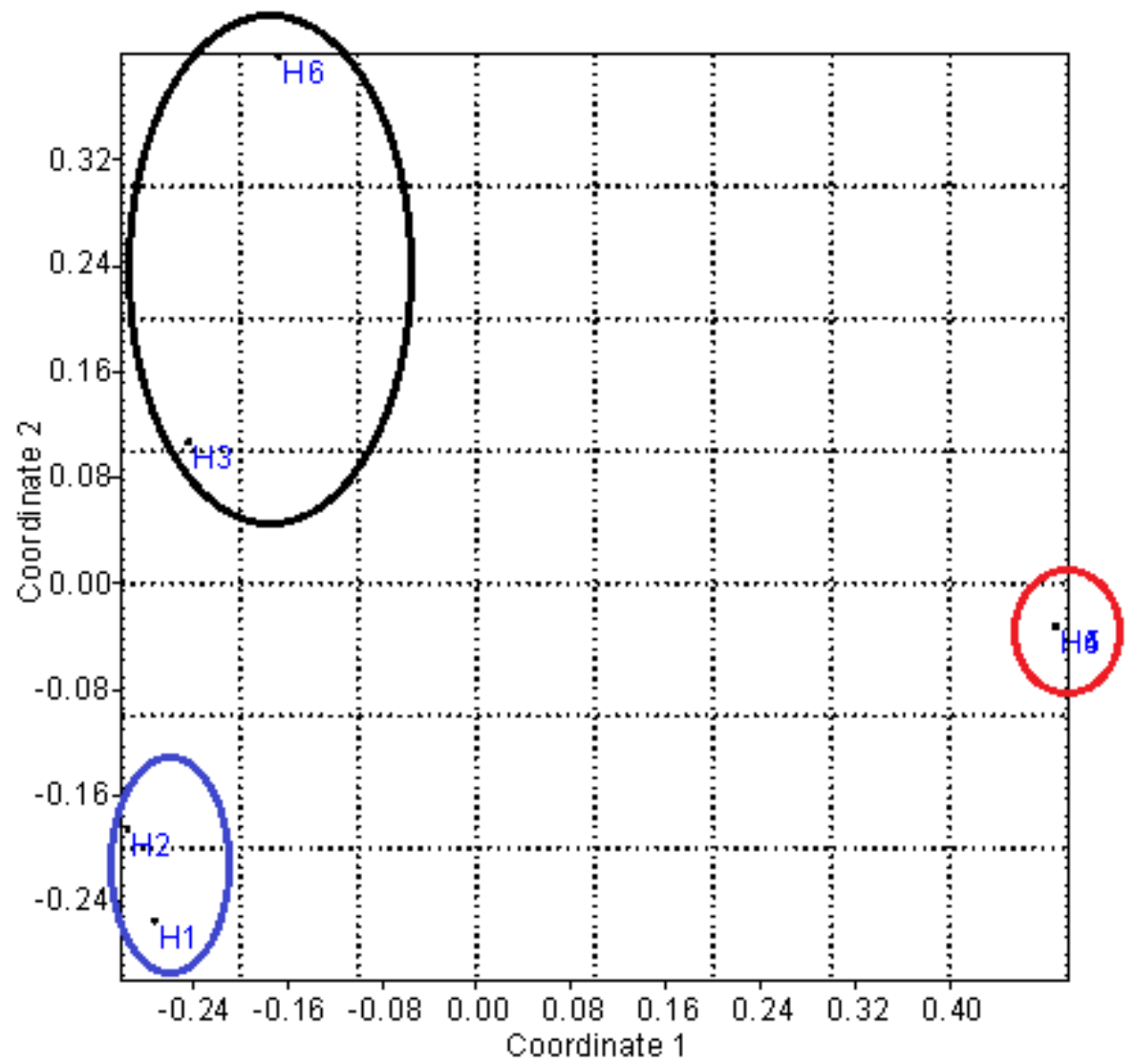

Figure 5. Non-metric multidimensional scheduling (nMDS) analysis. Group 1 (H1 and H2) in blue, Group 2 (H4 and H5) in red, and Group 3 (H3 and H6) in black.

\section{Discussion}

Bird songs requires muscle and neural activities, expending a considerable amount of energy. Southern House Wren sing more when body reserve is high, foraging success has been satisfactory or when environmental conditions are not metabolically demanding (Thomas, 2002). In other words, the periods with the highest singing frequencies (H1 and $\mathrm{H} 2$ ) may represent the periods with more favorable conditions for the vocalization.
Several hypotheses attempt to explain why the frequency of bird song is higher at dawn (Mace, 1987). According to Kacelnik and Krebs (1982) there are three possible explanation: 1) The transmission of sound is particularly more effective at this time of day, because certain microclimatic conditions are favorable for the sound transmission, such as low wind intensity and air turbulence; 2) The low level of light found at these times make it impossible for most of the birds to forage, as it makes it difficult to locate prey visually. 
In addition, insectivorous species as T. musculus have greater difficulty in locating prey at dawn due to the mild temperature recorded during this period reduce the activities of invertebrates. Birds do not overlap their daily activities (Thomas, 2002), population of Southern House Wren can reserve this time of day for the emission of songs; 3) Due to the availability of territory at dawn, due to mortality at night. With this, newly arrived males seek the invasion of territory, and singing is an important tool for such activity. Southern House Wren are rather territorialist (Pereira, 2015), with several reports of elimination of competitors intra and interspecifically from their territories. It is also known that Southern House Wren invade other birds nest to destroy their eggs without even feeding on them (Santiago, 2009).

The morning choir is also related to reproduction, affecting the frequency of singing in birds. Males tend to increase it to attract a female (Dias, 2013), to ensure paternity through guarding female, chasing away rivals and attempting extra-pair copulation (Mace 1986, 1987) or by combining all these functions in their songs (Catchpole and Slater, 2008).

The periods with the highest temperatures and luminosity values are recorded during and close to noon in the city of João Pessoa (Santos et al., 2012), including sample periods (H4 and H5). No vocalization of $T$. musculus was recorded in these periods representing periods of the day that was unfavorable to the practice of singing activity. According to Henwood and Facrick (1979) model, the transmission at dawn could be up to 20 times more effective than at noon. Considering the Kacelnik and Krebs (1982) explanations mentioned above, the high temperature and luminosity found during the periods around noon (H4 and H5) in João Pessoa, increase the detection of preys by birds. In this way, they concentrate their energetic reserves for the practice of foraging in these periods.

According to Siciliano and Tavares (2011), the periods with highest activity of birds are in the early hours of the day, until $10 \mathrm{am}$, or in the late afternoon, from $3 \mathrm{pm}$ to sunset. The $\mathrm{H} 3$ and $\mathrm{H} 6$ periods comprise the end of the vocalization activity in the dawn and dusk, respectively. These periods represent a expensive energetic cost to vocalize due the lowest success in a effective communication. Santos (2014) states that the most bird species have peak of vocalization in the late afternoon, when they begin to look for places to stay overnight. That means that singing serves as a form of communication and possession of territory.

\section{Conclusion}

The individuals of Troglodytes musculus evaluated sing more frequently in the early morning and less frequently at dusk, with an intercalated period without vocal record. The dawn is the period with greater activity of Southern House Wren to present the greatest records of marking or invasion of territory (favorable environmental conditions to the dissipation of vocals) and less successes in foraging, reserving this period to the emission of songs.

The periods nearly to midday were less effective for the transmission of songs in relation to the dawn and the resumption of acoustic records at dusk due to the search and demarcation of places to stay overnight.

\section{Supplementary material}

Supplemental material including one sound file can be found with this article online at https://doi.org/ 10.21472/bjbs.050914-s. 


\section{Conflict of interests}

The authors declare that there are no conflicts of interest.

\section{References}

Alvares, C. A.; Stape, J. L.; Sentelhas, P. C.; Gonçalves, J. L. M.; Sparovek, G. Köppen's climate classification map for Brazil. Meteorologische Zeitschrift, v. 22, no. 6, p. 711-728, 2014. https://doi.org/10.1127/ 0941-2948/2013/0507

Blendinger, P. G. Abundance and diversity of small-bird assemblages in the Monte desert, Argentina. Journal of Arid Environments, v. $61, \quad$ no. $4, \quad$ p. $567-587,2005$. https://doi.org/10.1016/j.jaridenv.2004.09. 017

Brown, J. Troglodytes musculus. 2003. Available from: <http://www.animal diversity.ummz.umich.edu/accounts/troglod ytes/t._aedon\$narrative.html>. Accessed on: May 15, 2017.

Catchpole, C. K.; Slater, P. J. B. Bird song: biological themes and variations. Cambridge: Cambridge University Press, 2008.

Dias, A.F.S. Competição por espaço acústico: adaptações de cantos de aves em uma zona de alta biodiversidade do Brasil Central. Brasília: Universidade de Brasília, 2013. (Thesis).

Dias, S. C.; Candido, D. M.; Brescovit, A. D. Scorpions from Mata do Buraquinho, João Pessoa, Paraíba, Brazil, with ecological notes on a population of Ananteris mauryi Lourenço (Scorpiones, Buthidae). Revista Brasileira de Zoologia, v. 23, no. 3, p. 707710, 2006. https://doi.org/10.1590/S010181752006000300014

Fasanella, M.; Fernández, G. J. Alarm calls of the Southern House Wren Troglodytes musculus: variation with nesting stage and predator model. Journal of Ornithology, v. 150, no. $4, \quad$ p. $853-863,2009$. https://doi.org/10.1007/s10336-009-0406-2

Granzinnolli, M. A. M.; Motta-Junior, J. C. Aves de rapina: levantamento, seleção de habitat e dieta. In: Matter, S. V.; Straube, F.; Accordi, I.; Piacentini, V.; Cândido-Jr., J. F. (Orgs.). Ornitologia e conservação: ciência aplicada, técnicas de pesquisas e levantamento. Rio de Janeiro: Technical Books, 2010. p. 169-187.
Henwood, K.; Fabrick, A. A quantitative analysis of the dawn chorus: temporal selection for communicatory optimization. The American Naturalist, v. 114, no. 2, p. 260-274, 1979. https://doi.org/10.1086/ 283473

Kacelnik, A.; Krebs, J. R. The dawn chorus in the great tit (Parus major): proximate and ultimate causes. Behaviour, v. 83, p. 287309, 1982. https://doi.org/10.1163/15685 3983X00200

Köppen, W. Versuch einer Klassifikation der Klimate, vorzugweise nach ihren Beziehungen zur Pflanzenwelt. Meteorologische Zeitschrift, v. 18, p. 106120, 1901.

Kroodsma, D. E.; Byers, B. E. The function(s) of bird song. American Zoologist, v. 31, no. 2, p. 318-328, 1991.

Llambías, P. E. How do Southern House Wrens Troglodytes aedon musculus achieve polygyny? an experimental approach. Journal of Ornithology, v. 153, no. 2, p. 571578, 2012. https://doi.org/10.1007/s10336011-0778-y

Mace, R. Importance of female behaviour in the dawn chorus. Animal Behavior, v. 34, p. 621-622, 1986. https://doi.org/10.1016/ S0003-3472(86)80139-7

Mace, R. Why do birds sing at dawn. ARDEA Netherlands Ornithologists' Union, v. 75, p. 3-132, 1987.

Marini, M. A. Effects of forest fragmentation on birds of the Cerrado Region, Brazil. Bird Conservation International, v. 11, p. 13-25, 2001. https://doi.org/10.1017/S09592709 01001034

Maynard-Smith, J.; Harper, D. Animal signals. New York: Oxford University Press, 2003.

Pereira, M.S. Assembleia de aves territorialistas na formação espinilho: densidade e seleção de habitat reprodutivo. Porto Alegre: Pontifícia Universidade Católica do Rio Grande do Sul, 2015. (Graduate dissertation).

Santiago, R. G. Corruíra ou cambaxirra (Troglodytes (aedon) musculus). Biblioteca Digital de Ciências. 2007. Available from: <https://www.bdc.ib.unicamp.br/bdc/>. Accessed on: May 15, 2016.

Santos, J. S.; Silva, V.P. R.; Lima, E. R. V.; Araújo, L. E.; Costa, A. D. L. Campo térmico 
urbano e a sua relação com o uso e cobertura do solo em cidade tropical úmida. Revista Brasileira de Geografia Física, v. 5, no. 3, p. 540-557, 2012. Available from: $<$ https://periodicos.ufpe.br/revistas/rbgfe/a rticle/view/232851/26843>. Accessed on: May 15, 2016.

Santos, K. K. Aves da RPPN Alto Montana, Serra da Mantiqueira, Itamonte-MG. Itamonte: Instituto Alto-Montana da Serra Fina, 2014. Available from: <https://www.sosma.org.br/wpcontent/uploads/2014/07/AVES-DA-RPPNALTO-MONTANA.pdf>. Accessed on: May 26, 2016.

Siciliano, S.; Tavares, D. C. Voo pela Fiocruz: guia de aves do campus. Rio de Janeiro: 2011. Museu da Vida, Casa de Oswaldo Cruz, Fiocruz, 2011.

Sick, H. Ornitologia brasileira. 2. ed. Rio de Janeiro: Nova Fronteira, 1997.

Sick, H. Ornitologia brasileira. 3. ed. Rio de Janeiro: Nova Fronteira, 2001.
Silva, L. M. T.; Braga, R. B. Parque Natural Municipal do Rio Cuiá, em João Pessoa, Paraíba: subsídios geográficos para o plano de manejo. Revista OKARA: Geografia em Debate, v. 11, no. 1, p. 92-104, 2017. Available from: <http://www.periodicos. ufpb.br/index.php/okara/article/view/3080 7/18013>. Accessed on: Feb. 15, 2018.

Slabbekoorn, H.; Smith, T. B. Bird song, ecology and speciation. Philosophical Transactions of the Real Society of London B, v. 357, p. 493-503, 2002. https://doi.org/ 10.1098/rstb.2001.1056

Thomas, R. J. The costs of singing in nightingales. Animal Behaviour, v. 63, no. 5, p. 959-966, 2002. https://doi.org/10.1006/ anbe.2001.1969

Voos, W. A.; Sander, M. Frutos de árvores nativas na alimentação das aves. Trigo e Soja, v. 51, p. 26-30, 1980. 